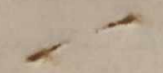

\title{
Seleção de Pessoal e Classificação de Cargos
}

A classificação de cargos pelo critério da natureza, dificuldade e responsabilidade das atribuições é um dos mais antigos reclamos do funcionaslimo público civil. No entanto, só ùltimamente pôde ser posta em têrmos práticos, através de dois projetos de lei que foram submetidos à apreciação do Poder Legislativo.

Dizer das vicissitudes que assinalaram a discussão do primeiro dêsses projetos seria fazer a crônica do malôgro de uma ǵrancie iniciativa sacrificada pela ambição de alguns e pela incompreensão de muitos; falar das dificuldades que vêm tornando tão penosa a tramitação do segundo numa das casas do Congresso seria dar um dopoimento desnecessário, pois os fatos aí estão diante de quem os queira apreciar.

O que se pode dizer a respeito, por não ser matéria de observação comum, é que sòmente depois que se consolidou o sistema dos concursos, e através dêle se fixaram, com a indispensável fixmeza, as características da maioria dos cargos e funções do serviço público federal, tornou-se viável a elaboração dos dois citados planos.

Considerados êsses fatos, compreende-se por que a classificação de cargos, apesar de reivindicada há longos anos,' só recentemente veio a ser formulada em têrmos de realização.

Não é por obra de simples acaso que as disputas suscitadas pelos dois projetos de classificação envolvem, sobretudo, cargos ou funções que circunstâncias especiais mantiveram do alcance do sistema do mérito. Não tendo sido objeto de concursos ou de provas de habilitação tais cargos ou funções, geralmente de títulos imprecisos, não tiveram suas atribuições estabelecidas com antecedência, para que em relação a elas o tempo exercesse os naturais ajustamentos. Só se cogitou de definí-las por ocasião dos inquéritos exigídos pela elaboração do primeiro plano de classificação de cargos e funções, quando, então, certas situações pessoais já haviam disfarçado inteiramente a realidade.

Desde cedo era de prever-se, por isso mesmo, a divergéncia entre os que teriam de elaborar o plano, partindo da realidade, e os 
que iriam apreciá-1o, partindo de uma concepção que tomava as coisas pela sua aparência, ou pelo menos as idealizava conforme sugeria um ilusório bom senso.

A maioria dos cargos e funções só não teve a mesma sorte, porque o sistema do mérito, no exercício de suas atividades normais, já lhes pesquisara os tipos de trabalho característicos, os conhecimentos e aptidões a êles correlatos. Quando surgiu o problema da elaboração do plano de classificação, êsses cargos já se achavam definidos de maneira estável, quer quanto ao seu conteúdo, quer quanto aos requisitos para o seu provimento. Não havia, assim, margem para mais de uma concepção a respeito, não se justificando, portanto, divergências de maior significação. Nesta hipótese, o inquérito especial promovido pelos elaboradores do plano de classificação de cargos poderia ter caráter complementar e visar ao conhecimento de certos aspectos não abrangidos pelas análises feitas para fins de concursos e provas de habilitação.

Como se vê as relações entre a seleção e a classificação de cargos apresentarem, no caso particular do serviço público federal brasileiro, nuances outras além daquelas que a doutrina costuma pôr em relêvo, quando confronta os dois problemas fundamentais da administração de pessoal. Tais relações perdurarão, ainda com feição peculiar, uma vez aprovado o plano de classificação, qualquer que êle seja, pois, determinadas questões da seleção, hoje solucionadas mediante simples provimentos administrativos virão a ser consolidados na lei de classificação.

Daí resultará, certamente, maior estabilidade para os processos de seleção, os quais ficarão menos sujeitos às flutuações dos interêsses e pontos de vista dos chefes de serviço. Também o recrutamento dos candidatos a concursos e provas para ingresso no serviço público sofrerá os influxos benéficos da lei de classificação, porque esta the dará os vários instrumentos das especificações legais dos cargos e funções.

Por outro lado, como a classificação de cargos é, por definição, um processo contínuo e os reajustamentos a que ela deve submeter-se são indicados pelas modificações nas exigências para o provimento đos cargos e funções, a seleção de pessoal ainda the poderá prestar novas contribuições.

Classificação de cargos e seleção de pessoal são problemas que se interpenetraram, e se mantêm em constante simbiose, cada um dando ao outro e do outro recebendo elementos fundamentais. 